\title{
The Embodied Subjectivity of a Half-Formed Narrator: Sexual Abuse, Language (Un)formation and Melancholic Girlhood in Eimear McBride's A Girl is a Half-Formed Thing
}

\author{
Shadia Abdel-Rahman Téllez
}

University of Oviedo, Spain

Copyright (c) 2018 by Shadia Abdel-Rahman Téllez. This text may be archived and redistributed both in electronic form and in hard copy, provided that the author and journal are properly cited and no fee is charged for access.

\begin{abstract}
Set in Ireland, in some undetermined time and place, Eimear McBride's A Girl is a Half-formed Thing (2014) is a story about the crisis of identity of a nameless girl who has been sexually abused by her uncle in her teens. The aberrant sexualisation resulting from rape and the socially pre-established discourses of girlhood and womanhood provoke the fragmentation of the protagonist's identity as a female subject and her transformation into a "half-formed thing". McBride tries to capture this process of half-formation by means of language and other experimental narrative strategies, which are a clear legacy of modernism and the works by female writers from the Celtic Tiger period. The violent world, in which the main character is under the rule of her authoritative mother and predatory uncle, contrasts with the loving relationship with her terminally ill brother. The melancholic experiences of shame and guilt invade the Girl's sense of embodied identity and interfere with the process of becoming an individual. The death of her brother is the ultimate trigger for the half-formed girl to disengage permanently from her "sinful" body, opening the possibility of an alternative mode of being in the world. The analysis of this novel-long stream-of-consciousness focuses on the narration of the conflicts with corporeality, abnormal sexualisation, the dissolution of subjectivity and failure to regain agency over a powerless body.
\end{abstract}

Key Words. Embodiment, sexual abuse, girlhood, melancholia, stream of consciousness, experimental language.

Resumen. Ambientada en Irlanda en un tiempo y lugar indeterminados, A Girl is a Halfformed Thing (2014) de Eimear McBride es un relato sobre la crisis de identidad de una joven anónima abusada sexualmente por su tío durante su adolescencia. La sexualización aberrante como consecuencia de la violación y los discursos socialmente preestablecidos sobre niñez y femineidad son la causa de la fragmentación de la identidad de la protagonista como sujeto femenino y su transformación en una "cosa a medio formar". McBride intenta capturar este proceso de formación incompleta por medio del lenguaje y otras estrategias narrativas 
experimentales, las cuales son un evidente legado del modernismo y de las obras de escritoras del periodo del Tigre Celta. El mundo violento en el que el personaje principal se encuentra bajo el yugo de una madre autoritaria y un tío depredador sexual contrasta con la relación de afecto con su hermano enfermo terminal. Las experiencias melancólicas de vergüenza y culpa invaden el sentido de identidad corporal de la protagonista e interfieren en su proceso de transformación como individuo. La muerte de su hermano es el detonante decisivo para que la joven decida separarse definitivamente de su cuerpo "inmoral", abriendo la posibilidad a una nueva forma de "vivir en el mundo", entendida como una experiencia no corpórea. El análisis de esta novela escrita en forma de flujo de conciencia (stream of conciousness) se centra en la narración de los conflictos de corporeidad, la sexualización anormal, la disolución de la subjetividad y la imposibilidad de recuperar el control de un cuerpo indefenso.

Palabras clave. Encarnación, abuso sexual, niñez, melancolía, flujo de conciencia, lenguaje experimental.

A Girl is a Half-formed Thing (2014) is Irish author Eimear's McBride debut novel, winner of several literary awards and praised by most critics, who agree in its literary quality and richness. McBride wrote her novel about ten years before its publication, that is, during the Celtic Tiger years, a period in which there was a "predominance of narratives about siblings ... with women's writing particularly interested in stories of brother-sister relationships" (Bracken 25). The protagonist's bond with her brain-damaged and terminally ill brother will be one of the pivots of the storyline. However, the focus on her role as a sister fades into the background, when she experiences a pubertal sexual awakening that triggers a constant preoccupation about a body she believes has been profaned by desire and lust. Her crisis of identity is worsened when she is raped by her uncle, an event that causes her struggle to define herself, not only as a woman, but as an individual. Thus, as the Girl grows up, the physically and emotionally painful experiences she goes through and the patriarchal society in which she is immersed contribute to the fragmentation of her identity and the distortion of her sense of embodiment. Her dominating grandfather, her absent father, her ill brother and her predatory uncle are the male archetypes in this novel, while her mother, devoted to religion, is the only female model available for the protagonist. Trapped in an oppressive world, the Girl has only two options: obey or rebel.

McBride skilfully expresses the disintegration of the protagonist's embodied identity by means of different stylistic and symbolic elements. In this regard, the analysis of this novel-long stream-of-consciousness focuses on the narration of the conflicts with corporeality, the dissolution of subjectivity and the failure to regain agency over a powerless body. The first section is devoted to the author's appropriation of the stream-of-consciousness technique as an experimental narrative mode to represent the initial genesis or formation of the central character's subjectivity. Secondly, namelessness will be analysed as an authorial strategy to deal with the main character's identity problems in relation to girlhood; in fact, the novel will be approached as the consolidation of the girlhood narratives as a genre in the Irish literary tradition. Thirdly, the protagonist's distorted conception of sex and female sexuality will be studied as a consequence of the pain and powerlessness experienced in sexual abuse and the fragmented language of narration as a symptom of the un-formation of subjectivity. Finally, the main character's conflicts with her corporeality will be defined in terms of two dissociative disorders: melancholia and depersonalisation, two conditions that caused her feeling of shame and guilt and led to story's tragic ending, in which death is depicted as an alternative mode of being-in-the-world. 


\section{Experimental Narration and Half-Formed Subjectivity}

Bearing Arthur W. Frank's conception of the wounded storyteller in mind, stories about physical suffering are narrated through the body. However, the narration of experience through corporeality can be rather problematic, since "the body eludes language" (2). In order to reflect the difficulty to translate the protagonist's embodied subjectivity into verbal language, the author has devised and experimented with different narrative, symbolic and linguistic elements, resulting in the writing of a novel-long stream of consciousness, in which the perspectives adopted by the narrator defy realism.

The first part of the book, "Lambs", starts with a brief narration about the world that existed before the nameless protagonist was born. The Girl narrates her "beginning", when she is still in her mother's womb, describing a world to which she still has no access: "Poke belly of baby that's kicking is me. Full in myself. Bustling hatchery. And I loved swimming to your touch. Lay on the lining for your strokes for you secret pressed hello's. ... See you and me were busy with each other long before I came" (5). By adopting this perspective, the Girl presents herself as an impossible or "unnatural" narrator because her point of view "transcend[s] real-world possibilities by projecting physically, logically, or humanly impossible scenarios or acts of narration" (Alber, Nielsen and Richardson 351). She starts her account when she is still unformed and not ready to enter the outside world. Consequently, as the main character of an experimental novel, her narration as a conscious, unborn girl has two functions. On the one hand, she highlights the strong bond she had with her older brother, who suffers from a brain tumour that constrains his cognitive development and who is the "you" to which the Girl addresses in her narration. On the other hand, she introduces two different beings-in-the-world, which are related to the so-called "phenomenology of perception".

The Girl compares the pure and sterile no-world she experiences in the maternal uterus and the "vinegar world" she discovers when she is born (McBride 5). Paradoxically, when she enters the world of perceptions, her senses do not help her apprehend it: "But I saw less with these flesh eyes. Outside almost without sight" (5). By starting the narration in a pre-physical and pre-linguistic period, the narrator establishes a dualistic division between the introspective world from which she narrates the whole novel and which is like a tabula rasa and the external world in which she learns that she has a (female) body: "I curled there learning limb from limb" (5). In addition, the representation of the protagonist's pre-verbal world allows readers to witness the birth of language itself, as well as the process of formation of embodied consciousness. Nonetheless, this genesis of language is transformed in the dissolution of speech due to the bodily trauma provoked by sexual abuse, as it will be seen below. The Girl is in a permanent position of liminality between formation and dissolution, which invades both her consciousness and her body.

McBride masterfully articulates in a narrative text the mental processes triggered by the protagonist's interaction with the outside world. From a phenomenological perspective, a stream-of-consciousness is an uninterrupted and unified flow of experiences (Dainton 4). McBride fictionalises the protagonist's unending thought-formation and represents this process by manipulating language. Language, in this regard, becomes purely experiential. In fact, in an interview, the author claimed that she wanted to narrativize the Girl's embodied experiences "on the moment just before language becomes formatted thought" (McBride, interviewed by David Collard). The Girl's streams of thought are like beams that she cannot process. The "I" that narrates embodied experiences is intermingled with the voice of other characters, as the narrator quotes fragments of dialogues with no formal distinction between her own thoughts and the words of others, as in the following excerpt: "She gets my hair. Listen. To me. Listen. What you've done. Shaking me smack and smack my head. Dirty brat. 
Shivering. Sharp with rage" (17). This narrative continuity and alternation between the Girl's consciousness and others' actions and words - reflected in the scarce use of commas, semicolons or colons - contrasts with the abrupt use of full stops to express the violent nature of some of her bodily experiences: "A slap for every word of warn we get. Never. Ever. Touch. That. dirty. Thing. It'll. Give. You. Warts. That. Is. Di. Sgust. Ing” (9). There is no fluidity in the narration, which consists in ungrammatical, short fragments about emotionally and physically painful experiences. The narrative streams of consciousness, consequently, can be interpreted as the translation of chaotic sensations into a narrative equally chaotic.

From a narratological point of view, the relationship between narrative streams of consciousness and experiential temporality is unclear. Some chapters are narrated retrospectively, while others are told as if experience and narration were simultaneous, i.e., in the present tense. Nonetheless, because there is certain maturity in the tone of the narrator and because her narration is addressed to her brother - who dies in the last part of the book - it can be said that experiences are narrated through the filter of memory and are mediated by her adult consciousness. The narration of past events as if they were present experiences may have two main purposes. On the one hand, the use of the present tense has the function of expressing the immediacy of pain and violence experienced during sexual abuse. Thus, in the detailed descriptions of sexual violence the narrator focuses on the "here and now" of the painful experience (Leder 75). On the other hand, narrating past actions in the present tense "may indicate a continuing preoccupation; the events are not contained in the past but rather continue to invade a narrator's current consciousness" (Ochs and Capps 25). The central concern of the Girl is undoubtedly her gendered corporeality.

\section{Namelessness, Girlhood and Half-Formed Identity}

The anonymity of the character has a powerful impact in the reading of the story. In A Girl is a Half-formed Thing namelessness of characters does not imply universality or the introduction of unimportant roles in the story. McBride's authorial decision has been indisputably influenced by the modernist writers who rendered their protagonists nameless, including Samuel Beckett (The Unamable), Storm Jameson (A Day Off), Ralph Ellison (Invisble Man) and more importantly James Joyce, the author's main source of inspiration. Joyce, like McBride, used anonymity in his works to deal with the identity conflicts of main characters (Culleton 20-21). The namelessness of McBride's character is an strategy to highlight her girlhood (readers can only refer to her as "the Girl") and her position in a maledominated world: "Because the power to name has rested since Adam with patriarchy, the female's position is doubly fixed - not only by a name that declares her gender but by one that bespeaks her male-defined identity" (Culleton 73). Her identity is defined by her gender when she is born and the doctor says: "There now a girleen isn't she great" (McBride 5). In addition, it is relevant to note that it was her brother that picked up the Girl's name (5).

Despite the anonymity of the main character and the lack of temporal and spatial specification, Susan Cahill notes in her analysis of girlhood, sexualisation and commodification in Post-Tiger literature that some references in McBride's novel set the events in "rural Ireland in the 1980s or 1990s" (159). Cahill argues that the publication of this book in Post-Tiger Ireland is rather pertinent, as it landed in a period in which girlhood has started acquiring visibility in the literary panorama. Until that moment, Irish boyhood had dominated childhood and coming-of-age stories, and Joyce's A Portrait of the Artist as a Young Man (1919/2005) clearly evinces that. Elizabeth Dougherty, in this sense, argues that childhood narrations have become a "male genre": "The Irish boyhood is canonized, prizewinning, best-selling, and even parodied. It constitutes a well-established literary genre of its own. By contrast, fewer works can be named as an example of the Irish literary girlhood" 
(50). The prestige of McBride's novel, described by Joshua Cohen in his review in The New York Times as a "future classic", reflects the new directions that Irish literary tradition is heading. McBride follows the path of canonical writers, but also of Irish women writers whose stories about childhood tend to be described as "obscure and often formally or stylistically peculiar" (Dougherty 50). McBride's work, thus, is the result of the development of Irish literary girlhood as a consolidated genre.

Back to the fictional representations of girlhood, in patriarchal societies, like the one in which the Girl is immersed, the transition from girlhood to womanhood is culturally preestablished, i.e., it is not the result of self-discovery and personal experience. This rigid female role is represented by the protagonist's mother, who sees herself as a respectful Christian woman. The transition from boyhood to manhood, in contrast, is characterised by a sexual awakening during adolescence, as Joyce represents in A Portrait of the Artist, where Stephen Dedalus experiences his recently discovered sexuality as a "brutish and individual malady of his own mind" (102). The Girl in McBride's novel experiences a pubertal sexual awareness in the same terms as Joyce's character, as she also perceives sexuality as something aberrant that goes against Christian morality. There is a clear disconnection between girlhood and womanhood in the experience of McBride's character. The preoccupation with sexuality is reflected in the change of the tone of the narration in Part II, titled as the novel. In this section, the protagonist experiences the physical changes caused by puberty. Even though menstruation is the most important step in the journey to becoming a woman, the Girl describes her transformation from a "lamb", a term that refers to the obedience and sense of sacrifice to God in Christian tradition, into a "half-formed thing", denoting her objectification and alienation derived from her own gender and the experience of sexual violence.

As a teenager, thus, the protagonist discovers a new flow of sensations that she could not define: "I sit bow-legged Encyclopaedia Britannica on my knee. Sex Sexism. Sexuality. All the words. I know it's something. ... Since I was ten and since I knew what men and women sometimes do but I am something else. I am. Going to the bad. To the somewhere new" (McBride 51). The protagonist, as Stephen Dedalus, defines her newfound sexuality as an individual and singular anomaly, since in comparison to her mother, a morally righteous woman, she sees herself as the abnormal. The embodied experience of the Girl, in this regard, is ambiguous: on the one hand, she experiences her new sexualised body as something "wrong" and on the other, she discovers the power of her sex. Thus, she narrates how, before the sexual abuse was produced, she felt observed by her uncle: "And in the kitchen I see him there [...] His eyes go with. I go ignore him. Stuffed throat as I walked past and could not think of how to shock. [...] Keep going. Not my single word for him. Not for him a lift of my eyes. I keep them locked" (51). This event and the subsequent sexual abuse triggered the protagonist's acceptance of her role as a visual delectation for men: "I am addling but good to be seen. It's very good to be seen" (87). Because the Girl is absorbed by a context in which female sexuality is tabooed and demonised, she interprets puberty as the cause of her conflicts with her embodied identity. Sexual abuse intensifies such conflicts and the feeling of corporeal and spiritual aberration experienced by the protagonist.

\section{Sexual Abuse and Half-Formed Thought}

In order to extinguish her first sexual awakening, the thirteen-year-old Girl decides to baptise herself again in a lake. She tries to leave her "wrong" body behind and recover her pure self:

Not for death or any other violent thing that I could do to myself. I am here this hour for. Storage I think. Cleaning and cold storage. ... I sink baptise me now oh lord and 
take this bloody itch away for what am I the wrong and wrong of it always always far from thee. Ha. My nose fill with that bog water. (55)

The protagonist's "sorry self" is "purged off" (56); she tries to get rid of what she thinks are deviant sexual desires. The Girl's drowning in the lake is a prolepsis of her tragic end, since, shortly after she is re-baptised, she is raped by her uncle, who represents the patriarchal power that controls female bodies.

In McBride's representation of sexual abuse, the invisibility of pain is a fundamental factor in the relationship between the Girl and her uncle. The private nature of the aggression does not allow the protagonist's attacker to know if she is in pain, neither visually nor verbally, resulting in the infliction of more pain. The Girl's first painful sexual experience illustrates the intrusion of pain in the body and consciousness:

Oh God. It hurts me take it out. ... Dance with the pain of it and I would do later for many bleeding days. Sting and itch. Not from disease. From new stretched and snapped skin. Up inside that will not fit in time. Expand and let him lurch there. I want. ... It hurts me. And kissing choking me. Almost too much of my body taken up. ... Coming out my eyes. My ears. Too much then. I'm taken over buckled onto him. (57-58)

In an attempt to bring visibility to a painful experience that is extremely private, the main character tries to transfer to her uncle the pain he is inflicting on her body by penetrating his skin with her nails:

I cannot cannot take this. Pain. Scratch him. Pain of it. Keep clawing at his skin. He does not. Does not know this. He is digging into me and me to him.... I. feel him filled with. Now. He filled with. My pain. ... I must be almost I am dying when he does it. With the pain. Suffocating. And his cheek. My nail my nail. That's it. I've done to him. What's done in me. (58; emphasis added)

This action allows her to externalise in the attacker the violence exerted upon her body, leaving a perceptible wound in her uncle's face. Nonetheless, because her uncle is abstracted in sexual pleasure, her response goes unnoticed. From that moment, what began as immediate temporal pain during a particular aggression became a latent pain present in all of her bodily experiences: "Think will it always hurt? Will I always bleed? When things are fit that tight how can there not be bruises?" (61). The traumatic impact of sexual abuse is absorbed in the Girl's embodied identity, which was already half-formed due to the social and religious constructions of femininity and is totally disintegrated with this first experience of sexual violence.

At the beginning of this violent scene, it seemed that the protagonist had the control of her body and the situation, showing her determination in not being his sexual object: "I know that look that vicious look of him to me now.... His want me. Fuck me if he could and I and I and I and I. .... Thanks uncle for sage introduce. I left him dripping in the door. Ha. He did not get me after all" (57; emphasis added). However, in the end she realises that her uncle actually holds the power: "Oh but he did. I'm lying. I am not I am. ... Felt within the time has come. No Christ here on the kitchen floor. ... And it was so quiet all around that I could hear him open me" (57). It is interesting the ambiguous use of the verb "lying". It can be interpreted in three different ways: her uncle did not get her and she is not saying the truth; her uncle got her and she is lying down; her uncle did get her but at the same time he did not. The last interpretation suggests the distorted view the Girl has about sex, as she conceives it 
as the experience of "momentary assertions of power and sustained self-harm, completely devoid of any expression of pleasure" (Cahill 159). The dynamics that regulate the hierarchical relationship in sexual abuse rendered her in an inescapable powerless position, as the narrator expresses when she bids farewell to her aunt and her uncle: "I was at his peck. Fairly passive" (60). However, the protagonist paradoxically thinks that, by means of submission in her sexual encounters, she is expressing her agency, which should be more accurately defined as a sort of passive agency. In addition, her uncle, a sexual predator, tries to keep the secrecy of his aggression by disguising sexual abuse as an affair, something that also contributes to the distortion of the Girl's notion of sex. She does not see her uncle as a sexual aggressor - neither does her uncle think he is a rapist. For that reason, thenceforth, the Girl interprets sex as a taboo experience necessarily violent and painful.

During her adulthood, the protagonist's sexual encounters with other nameless men become more and more aggressive and painful. She is frequently involved in situations in which she plays a passive, submissive role, as she summarises in this poetically rhythmic excerpt:

I met a man. I met a man. I let him throw me round the bed. And smoked, me, spliffs and choked my neck until I said I was dead. ... I met a man who hit me a smack. I met a man who cracked my arm. ... I met a man. And I lay down. And slapped and cried and wined and dined. I met a man and many more and I didn't know you at all. (96-97)

The Girl believes that in her casual sexual encounters she can show some kind of agency: "Saying yes is the best of powers" (71). In fact, she understands this kind of rendezvous as the relationship between an "obliged" and "obliging" person (149). Hence, because she "offers" her body as a sign of sexual availability, she believes she occupies the obliging position, "compelling" men to have sex with her. However, in most of the sexual intercourses narrated in the novel, she holds no power, constantly positioning herself in situations of vulnerability.

The triadic relationship between pain, language and powerlessness is quite remarkable in McBride's novel. Pain and violence, according to Elaine Scarry, are "language-destroying" (4). McBride captures this process of destruction using the most fragmented and unintelligible language to narrate physically and emotionally painful experiences. The whole novel can be interpreted as an attempt to capture the process of destruction of language. Playing with the pronunciation and musicality of the English language and alternating lower- and upper-case letters, McBride creates new language for her character to express the disintegration of speech, which in turn parallels the fragmentation of embodiment. The most violent aggression, occurred when the protagonist is sexually abused by an unknown man the same day of the wake for her brother, is encoded in the most obscure and discontinued language:

Hurts m. Jesus skreamtheway he. Doos the fuck the fuckink slatch in me. Scream. Kracks. Done fuk me open he dine done on me. Done done Til he hye happy fucky shoves upo comes ui. Kom shitting ut $\mathrm{h}$ mith fking kmg I'm fking cmin up you. Retch I. Retch I. Dinneradntea I choke mny. Up my. Thrtoat I. ... mY nose my mOuth I. VOMit. Clear. CleaR. He stopS up gETs. (McBride 149)

In this and many other experiences of sexual violence, the voice of the Girl is cancelled by the colossal voice of the aggressor, leaving her the only option of being a silent body. The opaqueness of language in this excerpt reflects that the speech formed in the Girl's stream of consciousness is immediately destroyed by bodily pain. There is, therefore, an incompatibility 
between the pain felt in the body and consciousness, indicating the protagonist's dualistic approach towards her embodied identity.

\section{Disembodiment and Melancholia}

The Girl was trying to evade not only physically painful experiences, but also emotional suffering. As already said, the "you" of the narration is the Girl's brother, to whom she feels closely attached. She and her brother were brought up in an environment in which both were powerless. During their childhood, they were on equal terms under the authority of their mother. However, their differences (his mental impairment and her gender and "sinful" sexualisation) made them grow apart from each other. While she continued maturing physically and mentally, her brother was stuck in his development. The brother's vulnerability is one the greatest frustrations of the protagonist, who feels impotent to protect him from the bullies at school or help him get better grades. She is actually a witness of her brother's decay. In this context, sexual victimisation was the ultimate link between the powerlessness the protagonist experienced at an introspective level and her physical powerlessness, a factor that had important consequences in her performance of disembodiment.

Short-term dissociation helped the Girl survive physical and sexual aggressions. During sexual abuse, mental abstractions allowed her to detach from immediate experience by disengaging from her body. In her first experience of sexual violence, the she tried to evade from the real world using her imagination: "I think and I think of painting houses. Streets with. Painting the town red. I must be almost I am dying when he does it. With the pain. Suffocating" (58). The pain and sadism inflicted on the main character's body triggered her efforts to disengage from a world over which she had no control: "I learned to turn it off, the world that was not my own. Stop up ears and everything" (61). In other experiences of sexual violence during her adulthood, the Girl tries to escape her body and evade from reality by praying (165) or singing (170). The most relentless episode of dissociation is produced in the chapter about the wake for her brother, when the uncle tries to use affection and paternalism to get a sexual benefit from his niece, who had just been brutally abused by the unknown man mentioned above. While her body is being assaulted, she recalls images and sensations of the lake where she used to swim and where she re-baptised her body:

Says come on now it's what's good you and us. Stick it ionthe don'tinside wwherhtewaterisswimming htroughmynoseandmouth throughmy-sense myorgands sthroughmythrough. ... Ithink i smell of woodwherethe river hits the lakebrownwashfoamy up the bank side Isee allcreaturesthere fish ducklings inthespring spring water going throughmyveins sinktheocean seeoutfar my salt my. Sea firsttime. Ahhhh pisses. ... He is done. Drop to earth. Tender. Can't smell this room. (197)

The lack of spaces between words symbolises the fluidity of water, as thoughts seem to flow the Girl's mind. However, this spacelessness in language also gives density and heaviness to the text, reflecting the perception of her body as an anchor that drags her self to darkness and depicting her world as a suffocating place. The language of this excerpt contrasts with the Girl's attempts to remember liberating bodily feelings and cancel the painful sensation that her body is actually experiencing.

The sexual abuse suffered by the protagonist distorted her sense of being-in-the-world and narrowed her world to a microcosm contained in her house, where she was powerless to construct her own identity distancing herself from the role model represented by her mother or to define her body as hers and not as the property of her uncle or other men. In this 
potentially depressive environment, the Girl starts experiencing a feeling of displacement in her home, even before experiencing sexual abuse, as she states: "The house is dry and creaky. ... I'm not at peace here anymore" (56). Martin Heidegger's phenomenological notion of "unhomelikeness" illustrates this idea. The Girl has a feeling of unhomelikeness in her physical home that mirrors her feeling of unhomelikeness in her abused body. Thus, in the same way that she tried to escape her home and find her own place going to college in London, she wanted to be liberated from her corrupted body.

In her new life as an independent college student far from her oppressive mother and her disabled brother, she finds freedom to negotiate her embodied experiences. Yet the experiences and the description of her bodily sensations seem to illustrate some of the symptoms of melancholia, or severe depression, a condition that Thomas Fuchs does not define as a mental illness, but as a "a corporealization of the lived-body" (237), i.e., "the body does not give access to the world any more, but stands in the way as an insistent and vexing obstacle" (238). The Girl has a distorted view of the world, which she perceives through a filter of darkness, i.e., through her body. Her description of London as a colourless and alienating place illustrates this point:

City all that black in my lungs. In my nose. Like I am smoking am not but still. I'll have a creaky bed up in some woman's house. ... This room smells of chalk smells bad to me. Go on. Jesus. Loads of people. Strangers coming going here. I see in this room rolling black boards is a new thing. But grills on windows is a what does that mean? I don't. Never seen that before. Ha. A wicked city I have come to. So all kinds of things must go on. I know. (McBride 83)

Although the Girl was eager to leave home, she realises that she is surprisingly homesick: "Oh. That's being lonely. ... And shocking. That. Homesick. I am. Oh God" (83). In her urban sexual re-awakening, the dirty and gloomy atmosphere in which her sexual encounters take place mirrors the way she approaches her sexualised body:

Crumbs on the carpets and insects bite my back I don't care for. Nicer is not what I am after. Fuck me softly fuck me quick is all the same once done to me. And washing in their rusted baths and flushing brown with limescale loos amid the digs of four a.m. before I put my knickers on. Say stay the night but I am gone. Down back stairs fag glued lip sore on and wait for, get the night bus home. (89)

The Girl changes one depressing environment for another even more depressing. In this sense, it is important to note that the title of the section in which the Girl leaves her home has a symbolic load. "Land under the Wave" or Tír fo Thuinn is the otherworld in Celtic folklore. The experiences narrated by the protagonist suggest that she feels like a living dead, but, instead of entering heaven, is trapped in an earthly purgatory.

The opaqueness and rigidity of the body of the protagonist is closely related to her feeling of shame and guilt. Living in a society with strict norms regarding female sexuality, the Girl feels shame from the unacceptability of her "spontaneous behaviour to expectations of others or the norms of decency" (Fuchs 227). Because she has internalised these social norms, shame is transformed into guilt. The Girl drifts apart from the "common world"; there is an intersubjective fracture between her and the others that "cannot be bridged again" (231). The regret from for her sinful "romance" with her uncle explains her decision to leave home and distance from her innocent, beloved brother. Guilt normally anchors the subject to a specific moment in the past. In the case of the Girl, she is dragged to the moment of her first sexual encounter with her uncle. The feeling of guilt is internalised by the protagonist to such 
point that it becomes part of her identity; guilt is, indeed, "bound to the process of individualization and of becoming a person - at least in western cultures" (239). Her selfimposed isolation from the world and the disruption of social bonds, thus, hampers the process of becoming a subject.

Unable to establish certain degree of intimacy and closeness in all her relationships with men (except for her brother), the Girl substitutes affection with violence. Thus, every time she experiences an emotional crisis that makes her feels powerless, she paradoxically finds in (violent and abusive) sex a way to express her impotence and sadness. The protagonist seeks bodily feelings to substitute the emotions she cannot deal with. In addition, intersubjectivity seems to be hampered by the lack of a shared language between the Girl and the others, which, along with the silence imposed by sexual trauma, renders her isolated from the social world. The idiolect used to narrate this story reflects this point: it is a language used to construct unshared thoughts.

When she finds out that her brother needs chemotherapy again, she desperately calls her uncle to find comfort: "Well I'm here doing what you want. Put yourself on me then, in me. Pull all other things out. It's no interest to me and. Throw me. Smash that all up. Do whatever you want. The answer to every single question is Fuck. ... Save me from all this" (131). The protagonist's aim at surviving in a ruthless world causes her desire of destroying a body that, apart from being perceived as shameful and sinful, is unable to feel or express emotions. It is a corpse that does not correspond with her "real" self: "And he kiss me all over like I am alive. ... Til I am hurt or I am sick. Keep going until I. Then you can let me die" (131-132). The lack of impulsiveness that characterises depression disappears during this sexual encounter, where she is able to feel something: pain. The Girl's paradoxical relationship with pain can be explained with the Cartesian neologism "Doleo ergo sum", which means: "I am a body, I feel pain. Therefore I exist" (O'Connor 74). The protagonist believes she is alive only by virtue of feeling pain. In addition, pain is a sort of selfpunishment, since the protagonist blames herself for her "affair" with her uncle. Yet the sensory stimuli the Girl experiences in this encounter are devastating to such a point that she claims she wants to die, i.e., be detached from her body permanently.

The "sense of gravity" (Micali 208) frequently experienced by depressed subjects is also represented in McBride's novel. The morning after the sexual encounter cited above, the protagonist feels her body trapped under her uncle's: "And him sleeping on me. Crush. That face in my elbow. He in my bed. ... I feel his body now like weights under water. Drag me down. I want. If I could be dead if I could be cut or broken up pushed underneath something feel my skin strip off' (McBride 132). The heaviness of her body simulates the pressure under water, an element that symbolises death and the standstill atmosphere of her houses, in Ireland and London. The protagonist feels her body as a burden or a corpse, comparable to the corpse of her deceased grandfather or her brother's body that is undergoing a long process of dying.

The impossibility to construct her identity and the emotional disinterest of the main character for a body that she continuously mortifies by means of sexual aggressions derives in the experience of depersonalisation, defined as "a detached and alienated attitude towards oneself, including one's body" (Colombetti and Ratcliffe 145). As already contended, the Girl feels estranged from her body when she starts experiencing the process of becoming a woman and is intensified after aberrant sexualisation: "This wrong doubtful body should not have been mine. Mine was. Not this. Was perfect" (McBride 162). However, this detachment is also extended to her self-concept: “... what's wrong here is me me me. Me the thing but I. Think I know. Is that the reason for what's happened? Me? The thing. Wrong. Strangling it is. Me" (162). By disengaging from her embodied identity, the Girl is, to some extent, objectifying herself. She is not a girl nor a woman; she is a thing, an empty subject, a corpse. 
The self-infliction of sexual pain, in this regard, has a double function in the embodied experience of the protagonist. On the one side, it can be a dissociative mechanism to punish the body, but, at the same time, it triggers the re-embodiment of the subject, for the Girl realises that she cannot separate mind from body. This reinforces her identity as a sinner and immoral woman, provoking her lack of identification with both her "sorry" self and her "wrong" body. This is the ultimate fragmentation of her half-formed identity.

\section{The Shattered Embodied Self}

The end of the protagonist of A Girl is a Half-Formed Thing is tragic. When her brother dies, the protagonist loses the only person that links her to her past innocent self and her infantile "pure" body. When she was born, her brother gave her not only a name, but also an identity: she was his sister. This role is what defines her; it is even more important than her relationship with her mother. The death of her brother was saddest event she has ever experienced, a feeling that parallels the most violent sexual aggressions she suffers. Her body, which has been abused by a man and her uncle the same day of her brother's vigil, is a deadweight. She sees no salvation for her: "I'm screaming in the blackness. Scream until I'm done my body. Full of nothing. Full of dirt the. I am" (194). At this point, readers realise that the novel is a retrospective narration about the Girl's suicide, as she recounts the experiences that provoked her ultimate dissociation between her self and her body: "Now you've. I. What's it like in the silence when. You. I. Where. I. Hello. Hello. Is he are you there? Ssssss. There? I'm only here in my bones and flesh. Now you've gone away" (198). The protagonist's flesh and bones are the material elements of her being that anchor her to a cruel and violent reality, while her spirit is still connected to her dead brother.

The half-formed Girl decides to go back to the lake to baptise herself for the last time: "Scrape me free of. Clean now. All the purity I can. There is for me here. Far out. Far out" (201). At this point, she reveals that she is a half-formed "thing" because she is a body, which has been punished and abused and which she wants to abandon: "Let water take the thing away. Take body" (202; emphasis added). The narrator opens an alternative mode of being-inthe-world, in which she does not have a physical body that can be gendered, stigmatised or damaged. Being out of her body will allow her to reencounter her deceased brother and recover the innocence that brings her closer to him: "Show me all the places of a soul. Where I will calm. And calm now. Give up dry land. I'm. Tired. Let it" (203). In this sense, the title of the last section of the book is rather relevant. "The Stolen Child" is a clear reference to W. B. Yeats poem, in which a child is enticed to enter a fairy world. Although the stolen child may be the Girl's brother, whom she still treated like a kid due to his illness, it may also refer to her suicide and her hope to find an afterlife in the real "land under the wave", where the sea and the sky merge, far away from the vinegar world, a world that is "more full of weeping" than she can understand (Yeats 16). She wants to be stolen by the fairies, go back to state anterior to sexualisation and become a child again. There is also a parallelism between the Girl's suicide and the ending of Joyce novel. Both Stephen Dedalus and the Girl take up exile from Irish society, although McBride's character does so in a more dramatic way, in the style of Kate Chopin's The Awakening (1899), where drowning is the only way to escape a patriarchal society and culture that controls female bodies and identities.

Water is a recurrent motif in Celtic Tiger narratives, as Bracken notes in her analysis of Sheridan's Disco Pigs, Kilroy's All Summer and Carr's Portia Coughlan. The Girl, as the characters of these texts, tries to dissolve their alienating subjectivity through water and "[t]his dissolving of the self is linked to the unknowability of an undetermined future" (Bracken 26) which is connected to the womb. In fact, her experience under water evokes her life in her mother's uterus in the first chapter of the book, although, instead of discovering the 
world of perception, she is undergoing the reverse process; she cancels all her sensory capacities. In addition, her namelessness has a symbolic significance at the end of the story. Leaving her body behind involves leaving her name, and her half-formed identity: "Turn. Look up. Bubble from my mouth drift high. Blue tinge lips. Floating hair. Air famished eyes. Brown water turning into light. There now. There now. That just was life. And now. ... What? ... My name is gone" (203). By no longer being a material body, i.e., a "thing", the Girl can finally achieve full disembodiment. Thus, in the same way that her body disappears in the bottom of the lake, her name and her past self vanish as she draws her last breath.

\section{Conclusions}

Rather than a coming-of-age story, A Girl is a Half-formed Thing is a story of unbecoming: unbecoming a girl, unbecoming a woman and unbecoming a lived body. Trapped in a sociocultural context that repressed female sexuality and where she was powerless, the Girl did not choose to either surrender or rebel, but both. Due to her aberrant sexualisation, she sought empowerment in violent sexual encounters, which only reinforced the dominance of her aggressors and her passivity. Sexual pain has a significant impact in the protagonist's sense of embodiment: it acts as a self-punishment for her profane sexualised body and as way to cope with emotional suffering. The fragmented streams of consciousness of the narrator represent the incompatibility between the violent external world and her introspective world, as well as the discordance between the linguistic structures of consciousness and the nonlinguistic nature of the body. McBride, thus, tries to capture the process of thought formation and its destruction in the language used in the narration. This results in the creation of a liminal language, which reflects the Girl's binary conflicts between girlhood and womanhood, power and passivity, body and spirit and subject and object. The melancholic experiences of shame and guilt invade the Girl's sense of identity, as they interfere with the process of becoming an individual. The Girl un-becomes someone and becomes something, i.e., a body which interferes with her real self. The only way for the Girl to leave her past immoral actions and save her spirit is to get rid of her embodied self and material body and become a no-body, understood as an alternative way of being in the world.

\section{Works Cited}

Alber, Jan, Henrik Skov Nielsen and Brian Richardson. "Unnatural Voices, Minds and Narration". The Routledge Companion to Experimental Literature. Ed. Joe Bray, Alison Gibbons and Brian McHale. New York: Routledge, 2012. 351-367.

Bracken, Claire. Irish Feminist Futures. Abingdon: Routledge, 2016.

Cahill, Susan. "A Girl is a Half-formed Thing?: Girlhood, Trauma, and Resistance in PostTiger Irish Literature". Lit: Literature Interpretation Theory 28. 2 (2017): 153-171.

Cohen, Joshua. "Bloody Hell. 'A Girl is a Half-formed Thing' by Eimear McBride". The New York Times, 19 September 2014. 24 January 2018. https://www.nytimes.com/2014/09/21/books/review/a-girl-is-a-half-formed-thing-byeimear-mcbride.html.

Collard, David. "Interview with Eimear McBride". The White Review. May 2014. 24 January 2018. www.thewhitereview.org/interviews/interview-with-eimear-mcbride/

Colombetti, Giovanna and Matthew Ratcliffe. "Bodily Feeling in Depersonalization: A Phenomenological Account". Emotion Review 4. 2 (2012): 145-150. 
Culleton, Claire A. Names and Naming in Joyce. Madison: The University of Wisconsin Press, 1994.

Dainton, Barry. Stream of Consciousness. New York \& London: Routledge, 2006.

Dougherty, Jane Elizabeth. "Nuala O'Faolain and the Unwritten Irish Girlhood". New Hibernia Review/Iris Éireannach Nua 11. 2 ( 2007): 50-65.

Frank, Arthur, W. The Wounded Storyteller. Body, Illness, and Ethics. Chicago and London: University of Chicago Press, 1997.

Fuchs, Thomas. "The Phenomenology of Shame, Guilt and the Body in Body Dysmorphic Disorder and Depression". Journal of Phenomenological Psychology 33.2 (2003): 223-243.

Joyce, James. A Portrait of the Artist as a Young Man. London: Collector's Library. 2005.

Leder, Drew. The Absent Body. Chicago and London: University of Chicago Press, 1990.

McBride, Eimear. A Girl is a Half-formed Thing. London: Faber and Faber, 2014.

Micali, Stefano. "The Alteration of Embodiment in Melancholia". The Phenomenology of Embodied Subjectivity. Ed. Rasmus Thybo Jensen and Dermot Moran. New York, Dordrecht and London: Springer, 2013. 203-220.

O'Connor, Peggy. "The Cartesian Mind in the Abused Body. Dissociation and the MindBody Dualism". Dimensions of Pain: Humanities and Social Science Perspectives. Ed. Lisa Folkmarson Käll. Abingdon: Routledge, 2013. 72-81.

Ochs, Elinor and Lisa Capps. "Narrating the Self". Annual Review of Anthropology 25.1 (1996): 19-43.

Scarry, Elaine. The Body in Pain: The Making and Unmaking the World. New York: Oxford University Press, 1985.

Yeats, W. B. The Collected Works of W. B. Yeats: Volume I: The Poems. Edited by Richard. J. Finneran. New York: Scribner, 1997.

Received: 31 October 2017 Revised version accepted: 29 January 2018

Shadia Abdel-Rahman Téllez graduated in English Studies and in the Master's Degree in Gender and Diversity at the University of Oviedo with a final dissertation about narrativity and embodied subjectivity in two literary representations of child sexual abuse and trauma. She is currently a PhD student in the Programme of Gender and Diversity in the University of Oviedo and her research interests include Medical Humanities and phenomenological philosophy. More specifically, her thesis examines literary representations of illness and pain in contemporary literature by women.

shadia-24@hotmail.com 